\title{
Temporal variability of methane emissions from a closed landfill at Denmark
}

\author{
Kissas, Konstantinos; Ibrom, Andreas; Kjeldsen, Peter; Scheutz, Charlotte
}

Publication date:

2021

Document Version

Publisher's PDF, also known as Version of record

Link back to DTU Orbit

Citation (APA):

Kissas, K., Ibrom, A., Kjeldsen, P., \& Scheutz, C. (2021). Temporal variability of methane emissions from a closed landfill at Denmark. EGU21-12518. Abstract from EGU General Assembly 2021.

\section{General rights}

Copyright and moral rights for the publications made accessible in the public portal are retained by the authors and/or other copyright owners and it is a condition of accessing publications that users recognise and abide by the legal requirements associated with these rights.

- Users may download and print one copy of any publication from the public portal for the purpose of private study or research.

- You may not further distribute the material or use it for any profit-making activity or commercial gain

- You may freely distribute the URL identifying the publication in the public portal

If you believe that this document breaches copyright please contact us providing details, and we will remove access to the work immediately and investigate your claim 
EGU21-12518, updated on 15 Mar 2021

https://doi.org/10.5194/egusphere-egu21-12518

EGU General Assembly 2021

(c) Author(s) 2021. This work is distributed under

the Creative Commons Attribution 4.0 License.

\section{Temporal variability of methane emissions from a closed landfill at Denmark}

Konstantinos Kissas, Andreas Ibrom, Peter Kjeldsen, and Charlotte Scheutz

Technical University of Denmark, Department of Environmental Engineering, Copenhagen, Denmark (konkis@env.dtu.dk)

Methane $\left(\mathrm{CH}_{4}\right)$ emissions from landfills contribute to global warming, impacting significantly the environment and human health. Landfill $\mathrm{CH}_{4}$ emissions strongly depend on changes in barometric pressure, inducing short-term $\mathrm{CH}_{4}$ emission variation of several orders of magnitude. Estimating the temporal variability of $\mathrm{CH}_{4}$ emitted into the atmosphere could help us reducing the uncertainties of annual emission estimates from landfills. In this study, we focus on the temporal variability of $\mathrm{CH}_{4}$ emissions under the impact of barometric pressure changes.

$\mathrm{CH}_{4}$ emissions of a closed landfill (Skellingsted, Western Zealand, Denmark) were measured with two different methods from December 2019 to June 2020; continuously with the eddy covariance method $(E C)$ and discretely with the dynamic tracer dispersion method (TDM). The EC method allows continuous measurements from a confined surface area, with most likely limited representativeness of the whole landfill site due to the considerable horizontal heterogeneity. The TDM method is able to quantify the emission from the whole site insensitive of the topography with the limited representativeness for the temporal variability.

$\mathrm{CH}_{4}$ emissions to the atmosphere measured by the TDM and fluxes measured by the EC ranged from to 0 to almost $100 \mathrm{~kg} \mathrm{~h}^{-1}$ and from 0 to $10 \mu \mathrm{mol} \mathrm{m} \mathrm{m}^{-1}$, respectively. The $\mathrm{CH}_{4}$ fluxes measured continuously using the EC method were highly correlated with the emissions from the periodic measurements using the TDM and fluctuated according to the pressure tendency. Under decreasing barometric pressure the highest $\mathrm{CH}_{4}$ emissions where observed, while increasing barometric pressure suppressed them almost to 0 .

Our results demonstrate the value of implementing two different complementary measurement techniques in parallel that will help to quantify total annual $\mathrm{CH}_{4}$ emission from a landfill. EC method provides continuous measurements describing accurately the temporal variation of emissions, while TDM method is able to quantify emissions from the whole site. 